8-1-2004

\title{
Perceptions of Domestic Violence in Lesbian Relationships: Stereotypes and Gender Role Expectations
}

Betsi M. Little

How does access to this work benefit you? Let us know!

Follow this and additional works at: https://commons.und.edu/theses

\section{Recommended Citation}

Little, Betsi M., "Perceptions of Domestic Violence in Lesbian Relationships: Stereotypes and Gender Role Expectations" (2004). Theses and Dissertations. 3802.

https://commons.und.edu/theses/3802

This Thesis is brought to you for free and open access by the Theses, Dissertations, and Senior Projects at UND Scholarly Commons. It has been accepted for inclusion in Theses and Dissertations by an authorized administrator of UND Scholarly Commons. For more information, please contact und.commons@library.und.edu. 


\title{
PERCEPTIONS OF DOMESTIC VIOLENCE IN LESBIAN RELATIONSHIPS: STEREOTYPES AND GENDER ROLE EXPECTATIONS
}

\author{
by
}

Betsi M. Little

Bachelor of Arts, Indiana University, 2000

\author{
A Thesis \\ Submitted to the Graduate Faculty \\ of the \\ University of North Dakota \\ in partial fulfillment of the requirements
}

for the degree of

Master of Arts

Grand Forks, North Dakota

August

2004 
This thesis, submitted by Betsi M. Little in partial fulfillment of the requirements for the Degree of Master of Arts from the University of North Dakota, has been read by the Faculty Advisory Committee under whom the work has been done and is hereby approved.

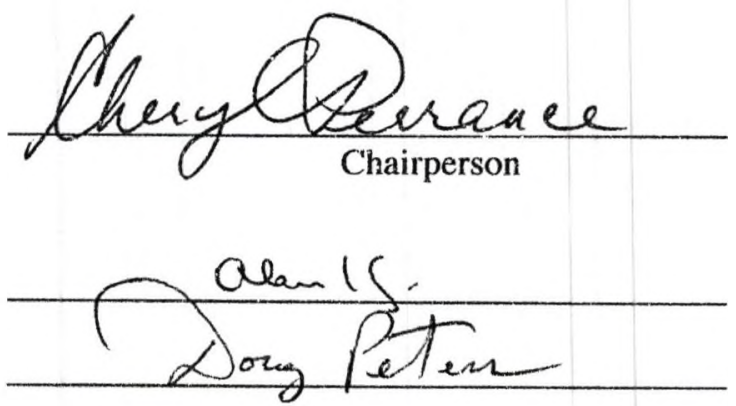

This thesis meets the standards for appearance, conforms to the style and format requirements of the Graduate School of the University of North Dakota, and is hereby approved.

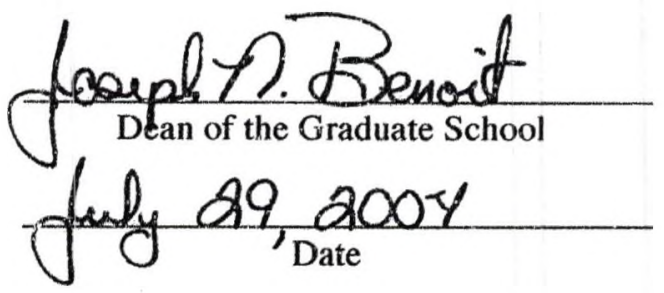




\section{PERMISSION}

Title Perceptio of Domestic Violence in Lesbian Relationships: Stereotypes and Genc. Role Expectations

Department Psycholog

Degree Master of Arts

In presenting this thesis in partial fulfillment of the requirements for a graduate degree from the University of North Dakota, I agree that the !ibrary of this University shall make it fretly available for inspection. I further agree that permission for extensive copying for scholarly purposes may be granted by the professor who supervised my thesis work or, in her absence, by the chairperson of the department or the dean of the Graduate School. It is understood that any copying or publication or other use of this thesis or part thereof for financial gain shall not be allowed without my written permission. It is also understood that due recognition shall be given to me and to the University of North Dakota in any scholarly use which may be made of any material in my thesis.

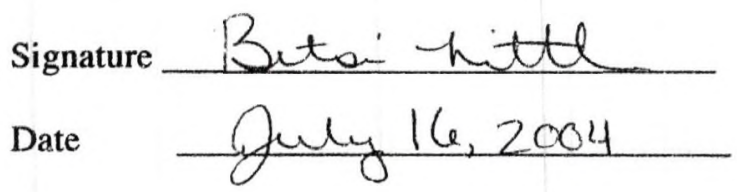




\section{TABLE OF CONTENTS}

LIST OF FIGURES $\ldots \ldots \ldots \ldots \ldots \ldots \ldots \ldots \ldots \ldots \ldots \ldots \ldots \ldots \ldots \ldots \ldots \ldots$

LIST OF TABLES $\ldots \ldots \ldots \ldots \ldots \ldots \ldots \ldots \ldots \ldots \ldots \ldots \ldots \ldots \ldots \ldots \ldots \ldots$ viii

ACKNOWLEDGMENTS $\ldots \ldots \ldots \ldots \ldots \ldots \ldots \ldots \ldots \ldots \ldots \ldots \ldots \ldots \ldots \ldots \ldots \ldots$

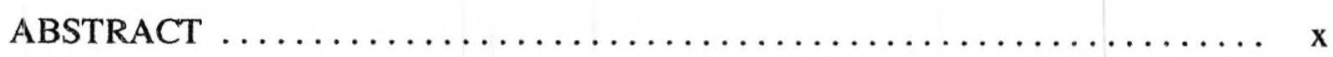

\section{CHAPTER}

I. INTRODUCTION $\ldots \ldots \ldots \ldots \ldots \ldots \ldots \ldots \ldots \ldots \ldots \ldots \ldots \ldots$

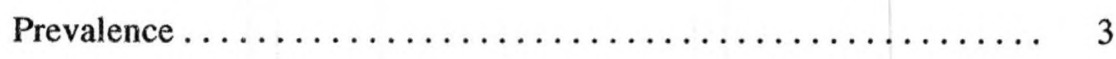

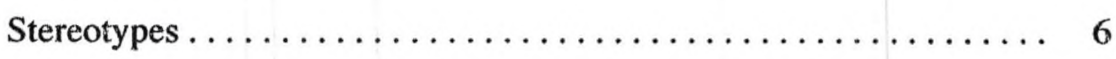

Gender-Based Stereotypes $\ldots \ldots \ldots \ldots \ldots \ldots \ldots \ldots$

Gender-Based Stereotypes and Intimate Relationships $\quad 10$

Gender-Based Stereotypes and Attribution of Blame in

Domestic Violence..................... 11

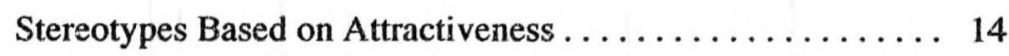

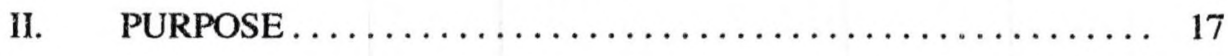

III. EXPCRIMENT 1: PHOTGRAPH VALIDATION $\ldots \ldots \ldots \ldots \ldots$

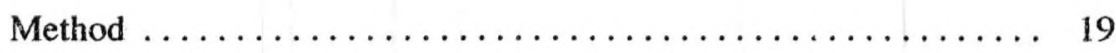

Participants......................... 19

Materials ........................ 19

Questionnaires....................... 19 
Attribution of Characteristics Scale ......... 19

Perceptions of Attractiveness . . . . . . . . . 20

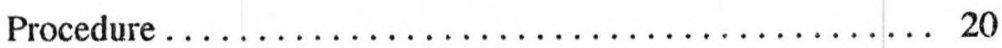

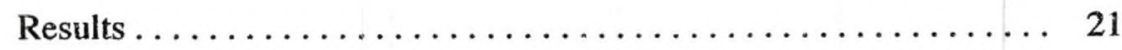

Attribution of Characteristics Scale $\ldots \ldots \ldots \ldots \ldots \ldots \ldots 21$

Perceptions of Attractiveness . . . . . . . . . . . . 21

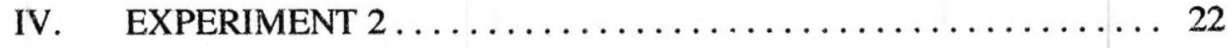

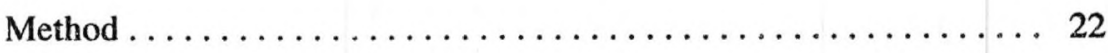

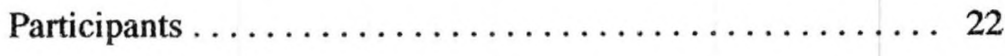

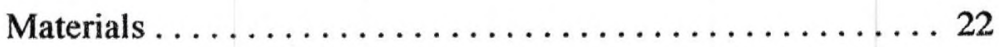

Vignettes ....................... 22

Photographs ..................... 22

Questionnaires.$\ldots \ldots \ldots \ldots \ldots \ldots \ldots \ldots \ldots \ldots \ldots \ldots$

Perceptions of Violence ............... 23

Perceptions of Attractiveness . . . . . . . . . . 24

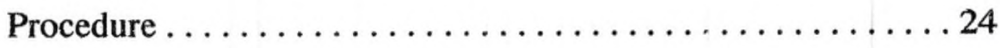

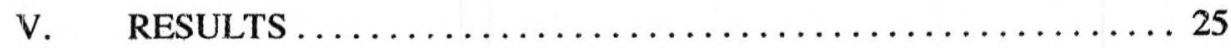

Perceptions of Violence Questionnaire . . . . . . . . . 25

Dangerousness of the Situation $\ldots \ldots \ldots \ldots \ldots \ldots 25$

Plausibility of the Claim .............. 25

Alleged Victim's Blameworthiness .......... 26

Accused Blameworthiness . . . . . . . . . 26

Perceptions of Attractiveness of Allpged Victim . . . . . . 27 
VI. DISCUSSION $\ldots \ldots \ldots \ldots \ldots \ldots \ldots \ldots \ldots \ldots \ldots \ldots \ldots \ldots \ldots \ldots \ldots \ldots \ldots$

Conclusion $\ldots \ldots \ldots \ldots \ldots \ldots \ldots \ldots \ldots \ldots \ldots \ldots \ldots \ldots \ldots \ldots \ldots$

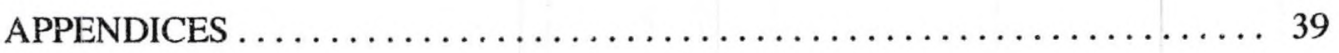

Appendix A: Photographs $\ldots \ldots \ldots \ldots \ldots \ldots \ldots \ldots \ldots \ldots \ldots \ldots, 40$

Appendix B: Attribution of Characteristics Scale ............ 41

Appendix C: Informed Consent Form: Perceptions of Physical Appearance . . . 44

Appendix $D$ : Debriefing Information $\ldots \ldots \ldots \ldots \ldots \ldots \ldots \ldots \ldots \ldots$

Appendix E: Vignette ......................... 46

Appendix F: Modern Homonegativity Scale . . . . . . . . . . 47

Appendix G: Perception of Violence Scale . . . . . . . . . . . . 49

Appendix H: Informed Consent Form: Perceptions of Relationships ....... 53

Appendix I: Debriefing Information $\ldots \ldots \ldots \ldots \ldots \ldots \ldots \ldots \ldots \ldots$

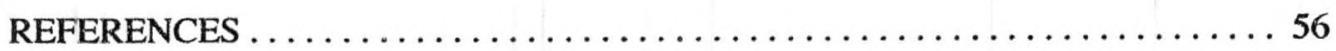




\section{LIST ('F FIGURES}

Figure

Page

1. Means for Victim Plausibility of Claim ............... 37

2. Means for Accused Blameworthiness . . . . . . . . . . . 38 


\section{LIST OF TABLES}

Table

Page

1. Means and Standard Deviations for Target Pictures as a Function of

Combined Attributions of Characteristics . . . . . . . . . . . . . 34

2. Means and Standard Deviations for Target Pictures as a Function of Attractiveness ................................. 35

3. Means and Standard Deviations for Plausibility of the Claim ........ 36 


\section{ACKNOWLEDGEMENTS}

I would like to acknowledge my Thesis Committee, Cheryl Terrance, $\mathrm{PhD}$.

(Chair), Alan King, PhD., and Douglas Peters, PhD. For their assistance, patience and guidance throughout this process. I would like to acknowledge my research assistants, Shelby Cartwright, Gina Garman, Nicole Krause and Ryan Schafer, for their hard work and dedication. I would also like to thank my friends and family for their support, understanding and love. 
To my ramily 


\begin{abstract}
In light of evidence suggesting that violence between lesbian couples is often times dismissed as "mutually combative," expectations that support this perception were examined in the present study. $T \rightarrow$ this end, undergraduate participants $(\mathrm{N}=287)$ read a newspaper brief describing an incident of domestic violence taking place within the context of a lesbian partnership. As gender-based stereotypes guide not only expectations for the behavior of lesbians, but their appearance as well, participants were shown pictures of both the alleged victim and accused that varied in terms of how feminine or masculine they appeared.

Participants were randomly assigned to one of five domestic violence batterer-victim conditions: Masculine-Feminine, Masculine-Masculine, Feminine-Feminine, FeminineMasculine and No Picture control. Participants were then asked to rate both the alleged victim and accused on a variety of measures including perceptions of responsibility and plausibility of the incident. Results indicated that the feminine appearing victim was more likely than the "masculine" appearing victim to be blamed for her own abuse. Among women, the victim tended to be believed more overall, however, victims claims were more supported when their abuser is characterized as masculine. These data support heterosexually-biased presumption in lesbian relationships. Implications of this research as well as future directions are discussed.
\end{abstract}




\section{CHAPTER I}

\section{INTRODUCTION}

During the past two cecades, the issue of domestic violence has come to be recognized as a serious social issue ( $\mathrm{Pitt}, 2000$ ). One aspect of this problem that has only recently received scholarly attention concerns violence that takes place within lesbian relationships. Challenging assumptions that domestic violence is primarily a heterosexual issue, studies suggest that domestic violence within lesbian relationships occurs nearly as often as it does in heterosexual relationships (Pitt, 2000; Turell, 2000). Despite this, violence within lesbian relationships is less likely than violence against women in heterosexual relationships to be reported by victims to authorities, less likcily to be prosecuted within the legal system and generally disregarded by helping agencies as well as the general public (Turell, 2000). The dismissal and invisibility of lesbian violence may in part stem from gender-based stereotypes that situate the roles of men and women in oppositional terms and support heterosexual-based assumptions concerning intimate relationships (Balsam, 2001).

Gender-based stereotypes support expectations regarding "appropriate" behavior for men and women (Hiton \& von Hipple, 1990). For example, women are stereotypically viewed as passive while men are seen as aggressive (Corely \& Pollack, 1996). Such stereotypes in turn support expectations regarding victims of domestic violence. That is, stereotypes delineating the roles of men $\approx$ nd women are reflected 
within characteristics typically ascribed to domestic violence victim" $n n^{\prime}$ fer $\mathrm{J}$ trs. Thus, within the context of heterosexual dorestic violence, women aic peiveived as the "legitimate" recipients of abuse, whereas men are seen as the perpetrators (Terrance, 2000). An implication of these expectations is that female to female violence may be perceived as less serious than male to female violence, in that women are not seen as aggressive (McLaughlin \& Rozee, 2001). At the same time however, lesbians are generally viewed as violating gender-based stereotypes guiding female behavior (Kite \& Deaux, 1987). Indeed, research indicates that people believe that lesbian women display characteristics and attributes of the opposite sex (Kite \& Deaux, 1987; MacDonald \& Games, 1974; Tripp, 1975; Weinberg, 1972). A consequence of such a stereotypical representation is that when violence occurs within a lesbian relationship, the violence risks not only being perceived as inconsequential, but also characterized as mutually combative (Burke \& Follingstad, 1999). Taken together, the combination of being perceived as not capable of severe aggression and yet not physically vulnerable, may contribute to the invisibility of lesbian victims of domestic violence.

Gender-based stereotypes extend beyond individuals and further serve to define intimate relationships within heterosexual terms (Corley \& Pollack, 1996). Specifically, intimate relationships become equated with male-female relationships (Corley \& Pollack, 1996; Kite \& Deaux, 1987; Storms, Stivers, Lambers, \& Hill, 1981; Viss \& Burn, 1991). Consequently, within the context of lesbian relationships, heterosexual-based assuraptions dictate that one partner will assume the heterosexual equivalent of the male role, while the other will assume the heterosexual equivalent of the female role (Corley \& 
Pollack, 1996). Such perceptions may thus explain the popular misconception that when violence does occur within lesbian partnerships, the perpetrator is characterized by masculine characteristics and the victim by feminine characteristics (Merrill, 1996). Not surprisingly, lesbians who appear "butch" or masculine, face skepticism by social service agencies and law enforcement when advi ncing claims of victimization (Balsam, 2001).

Taken together, these gender-based stereotypes likely impact the perception of violence that occurs within lesbian relationships. Although researchers have investigated perceptions of battered women in general, little research has examined perceptions of lesbians in violent relationships (Letellier, 1994). In light of pre-existing norms dictating appropriate female behaviors and stereotypical beliefs concerning lesbians, this study examined attributions of blame and responsibility for violence within a lesbian relationship.

\section{Prevalence}

Establishing rates of lesbian domestic violence is difficult due to negative attitudes that lead to the dismissal of claims as well as differing operational definitions of domestic violence (Pitt \& Dolan-Soto, 2001). Because the term "domestic violence" itself brings to mind the image of men beating women, there have been relatively few investigations into the prevalence of domestic violence in lesbian relationships (Turell, 2000). Because there is lack of acknowledgement that lesbian domestic violence does occur within relationships (Turell, 2000), official reports may under-represent the prevalence of violence within lesbian relationships. 
Studies that examine rates of violence within lesbian relationships have resulted in a wide range of frequencies. However, different definitions of same-sex domestic violence may in part contribute to these varying prevalence rates. For the most part, Hart's definition (1986) is the most commonly used and cited. Hart (1986) defines lesbian battering as a "pattern of violent or coercive behaviors whereby a lesbian seeks to control the thoughts, beliefs or conduct of her intimate partner or to punish the intimate for resisting the perpetrators control over her" (p 173). Individual acts of physical violence, by this definition, do not constitute lesbian battering. Moreover, according to this definition, physical violence is not considered battering unless it results in t: enhanced control of the batterer over the recipient.

Since it may be difficult to determine the motivation behind physical violence, some research conducted on this topic considers any form of aggressive physical contact battering. For instance, Brand and Kidd (1986) found that $17 \%$ of lesbians reported experiencing aggressive physical acts by their partners (i.e. hitting with hands or objects). Loulon (1987) and Wood (1987) conducted similar research to achieve their prevalence rates of $17 \%$ and $8 \%$ respectively. Likewise, Turell (2000), found that $9 \%$ of lesbians reported physical violence in their current relationships and $32 \%$ in their past relationships. Other surveys have found an even higher prevalence of violence in lesbian couples, reporting rates ranging from $17 \%$ to $60 \%$ (Bologna, Waterman \& Dawson, 1987; Brand \& Kidd, 1986; Lie \& Gentlewarrier, 1991; Lockhart, White, Causby, \& Isaac, 1994; Lie, Schilit, Bush, Montagne \& Reyes, 1991; Loulon, 1987; WaldnerHaugrud, Gratch, \& Magruder, 1997; Wood, 1987). 
Often, emotional abuse occurs at a higher rate in lesbian relationships than physical abuse (Lockhart et al., 1994). Investigations that include emotional abuse in their definition of battering have found significantly higher rates of abuse of $31 \%-83 \%$ (Bologna et al., 1987; Lie \& Gentlewarrio:- 1991; Lockhari et al., 1994; Turell, 2000). Examples of emotional abuse that were reported include ising verbally threatened with harm, abandonment or derogation. The most commonly reported form of emotional abuse was threatening to "out" the victim, resulting in homophobic reactions from coworkers, friends and family (Bologna et al., 1987; Lie \& Gentlewarrier, 1991; Lockhart et al., 1994; McLaughlin \& Rozee, 2001; Turell, 2000). However, lesbian violence is not limited to physical and emotional abuse. In fact, lesbians also report experiencing economic and sexual abuse (Turell, 2000).

Taken together, the prevalence rates of lesbian domestic violence are comparable with the national reported numbers of heterosexual women being battered in a relationship. According to 2001 statistics gathered from local, state and federal law enforcement agencies, $7 \%$ of women (3.9 million) are physically abused by their partners, and $37 \%$ (20.7 million) are verbally or emotionally abused. Considering even the lowest reported prevalence rate within lesbian relationships, lesbian battering appears to represent as much of a pervasive problem as it is within heterosexual couples (Pitt, 2000). Despite the prevalence of violence within lesbian relationships, the issue of lesbian battering is often dismissed. This dismissal may in part, reflect expectations that construct who is a "legitimate" victim. Such expectations may stem in part from genderbased stereotypes concerning men and women's roles within society. 


\section{Stereotypes}

Stereotypes are generalizations that allow people to divide the world into social groups. Social psychological research has demonstrated the power that stereotypes have in influencing the judgments people make on those around us (Esses, Haddock \& Zanna, 1993; Wittenbrink, Gist \& Hilton, 1997). Generally, stereotypes are learned through our own experiences or through observed interactions of others. Although stereotypes may reflect a "kernel of truth," they often represent generalizations regarding group membership that are distorted and generally incorrect (Hilton \& von Hipple, 1990).

The stereotyping process begins once a target has been identified as belonging to a stereotyped group. Specific characteristics are then ascribed to that person to form an impression of him or her (Brewer 1988). The target is then treated according to that generalization, often times without ever having had previous direct contact with the observer. In other words, observers make assumptions about a person's behaviors or appearance and then infer those traits to be his or her characteristics. An example of this includes seeing a woman who has a masculine appearance and assuming that she is a lesbian (Storms, et al., 1981). Once a "lesbian" has been identified as belonging to the "gay group" several other assumptions about this target may be made.

Irrespective of the inaccuracy of a stereotype, Hilton and von Hipple (1990, 1996) reported that stereotypes are maintained by seeking out confirming evidence which are often applied automatically and are resilient to change. In other words, stereotypes that stem from one's group membership are difficult to change because the observer seeks confirming evidence. Although stereotypes develop from membership within 
numerous groups, some of the most prominent stereotypes are those that arise from gender membership.

\section{Gender-Based Stereoiypes}

Stereotypes based on gender serve to define whom men and women are and support expectations as to how they should behave. Society constructs gender in oppositional terms: what men are, women are not, and vice versa (Renzetti, 1999). It is women's "nature" to be passive and dependent, while men are described most often as assertive (Hegstrom \& McCarl-Nielsen, 2002). Indeed, Maccoby (1990) found that men are socialized to be competitive, assertive, autonomic, self-confident and to have the tendency to not express intimate feelings. On the other hand, Noller (1993) found that women are socialized to be nurturing, warm and emotionally expressive.

Because of the tendency to assign masculine characteristics to lesbians and feminine qualities to gay men, beliefs about gay men and lesbians represent a special case of gender stereotypes (Storms, et al., 1981, Viss and Burn, 1991). Although some researchers have cited anecdotal information from personal experiences or through interviews to support this type of sex role reversal (Cogan, 1999; Zipkin, 1999), Kite and Deaux (1987) explained the beliefs associated with characteristics of lesbians and gay men in relation to inversion theory. Briefly, inversion theory describes the phenomenon that lesbians are characterized as having masculine traits and features and that gay men are described as possessing feminine traits and features.

In an examination of this theory, Kite and Deaux (1987) randomly assigned participants to one of four target conditions: heterosexual male, heterosexual female, 
homosexual male, homosexual female. Participants were asked to list all of the qualities that they thought were characteristics for their target and asked to rate the target on a probability scale. After sorting the characteristics given by participants, the task resulted in 208 attributes. Results indicated that whereas lesbians were described as masculine with masculine appearance, including wearing masculine clothing and having short hair, gay men were described in an equally feminine manner. In addition, lesbians were viewed as more similar to heterosexual men than to heterosexual women or gay men. Compared to the evaluations of heterosexual men and women, these types of attributes, and to whom they were assigned, support the inversion theory.

As suggested by the study conducted by Kite and Deaux (1987), stereotypical representations of lesbians serve to prescribe expectations not only about the traits and behaviors about lesbians, but their appearance as well. Indeed, Aube, Norcliffe and Koestner (1995) found that participants listed descriptions of physical appearance most often when describing characteristics of a masculine or feminine male or female. For example, characteristics ascribed to masculine females included short hair, masculine clothing, such as button down shirts and pants, and an athletic physique.

The association between one's gender and sexual orientation can be so robust, that when it has been demonstrated to be untrue, alternate explanations for the inconsistency is generated by the observer. For example, Storms, et al. (1981) investigated what happened when a target violates stereotype expectations within the context of a woman described as having homosexual or heterosexual feelings. They presented written descriptions of four female targets to student participants. Targets were 
described as possessing either masculine or feminine traits and having either sexual desire for women or sexual desire for men. Participants then rated the perceived sexual orientation of each target as well as a variety of personal attributes, such as mental health and stability.

Storms et al. (1981) found that there were indeed scripted expectations of lesbians and heterosexual women. Targets, who were described as masculine, were perceived as homosexual and those who were described as feminine were perceived as heterosexual. Similarly, those who were described as having homosexual feelings were perceived as being masculine and visa versa for the target described as having heterosexual feelings. These results indicate that information about either the gender-based characteristic or sexual orientation influenced the other. For targets in which those scripts were violated, (i.e. the masculine target described as having heterosexual feelings or the feminine target described as having homosexual feelings) participants found alternative stereotype-based expectations to fit the scenario. Specifically, those who violated the script were seen as confused, less mentally healthy and their sexual orientation less stable than stereotypeconsistent targets. These results suggest that, in general, people tend to negatively evaluate those who violate their concept of who a lesbian or heterosexual woman is.

Studies such as Storms et al. (1981) demonstrate how gender-based stereotypes guide expectations regarding men and women and what their behaviors and traits should be. Interestingly, these stereotypes are inversely associated with ones' sexual orientation. Whereas heterosexual women are described as feminine, lesbians are perceived as masculine. Further, the perceived association between gender and sexual orientation 
supports the contention that gender-based stereotypes support expectations that prescribe pariner preference. As Ponse (1978) notes, gender and sexual partner choice are presumed to be related in a highly consistent manner such that given one of the elements, the rest are expected to follow.

\section{Gender-Based Stereotypes and Intimate Relationships}

Gender-based stereotypes not only guide societal expectations of how men and women should behave but also how they should interact in a romantic relationship together. Research suggests that there is a societal belief that dictates who the "ideal" couple is (Corley \& Pollack, 1996). In other words, a woman is expected to be predominantly feminine in the performance of her sex-related roles and to orient her sexual preference toward males. On the other hand, men are expected to be masculine in the performance of his sex-related roles and orient his sexual preference towards females. Supporting these expectations, Regan and Sprecher (1995) found that men and women valued traditionaliy "male" characteristics, attributes, and contributions (e.g., have a high paying job and taking care of outdoor chores) more from a male partner than a female partner. Further, traditionally "female" characteristics, attributes, and contributions (e.g., taking care of children and indoor chores) were valued more from a female partner than a male partner.

Cejka and Eagly (1999) further demonstrated that certain characteristics are often translated into tangible gender-based responsibilities. For example, the male role is typically assumed to involve financial responsibilities, (i.e. being the breadwinner,) whereas the female role is generally presumed to encompass domestic responsibilities, 
(i.e. child-rearing). Corley and Pollack (1996) suggest that due to this stereotype, all romantic couples can be perceived as having some form of this masculine-feminine aspect, traditional of heterosexual couples.

Considered within the context of lesbian partnerships, a lesbian couple would ve perceived as having one masculine and eminine partner that adopt the dominant and submissive gender-based stereotypes respectively, in the relationship (Tripp, 1975; Peplau, 1983). This assignment of masculine and feminine roles in a lesbian relationship is not necessarily accurate (Cardell Finn \& Marecek, 1981; Kurdek, 1988). Indeed, lesbian couples are self-reportedly less gender-typed when compared to heterosexual couples (Caldwell et al., 1981). However, observers may not have first-hand knowledge of what constitutes a lesbian couple and therefore rely on hetercsexual-based assumptions concerning intimate relationships. The reliance on these assumptions regarding homosexual relationships have implications for perceptions of domestic violence allegations within lesbian partnerships. Indeed, perceptions of what it means to be a "legitimate" victim can directly contradict the stereotype of what it means to be a lesbian. Gender-Based Stereotypes and Attribution of Blame in Domestic Violence

Traditional gender-based stereotypes that define women as feminine, helpless, nurturing and dependent may also serve to support representation of the woman as the "legitimate" victim (Renzetti, 1999). Considered within the context of domestic violence, women who engage in behavior stereotyped as masculine, risk being negatively evaluated and deemed abnormal. For instance, women who fight back are often perceived as aggressive and therefore viewed negatively and unworthy of sympathy 
(Dodge \& Greene, 1991; Ewing \& Aubrey, 1987). Therefore, when a woman displays masculine characteristics, it is assumed that she is an aggressor in the violence, and thereby cannot be a victim of it. Gender-based stereotypes thus appear to play an important role in understanding why female victims of heterosexual domestic violence are viewed as either a legitimate or non-legitimate victim (Renzetti, 1999).

How these gender-based stereotypes would impact claims of victimization advanced by lesbian victims is unclear. Indeed, as previously discussed, lesbians are perceived as possessing traits associated with masculinity. At the same time however, masculine characteristics appear to be inconsistent with being perceived as a legitimate victim. However, no research to date has examined how victims of domestic violence within lesbian partnerships are perceived. In one of the few studies to address a similar issue, Harris and Cooke (1994) examined attributions of blame for domestic violence within the context of either a gay male partnership or a heterosexual relationship where the gender of the victim was varied.

Their results indicated that participants rated the gay male victim as less responsible for the incident than the husband victim, but more responsible than the wife victim. When the aggressor was gay, participants held him more responsible than the heterosexual female aggressor, but less responsible than the male heterosexual aggressor. Similarly when the question of arrest and conviction of the aggresser for the assault was asked, the gay batterer again fell in between the husband and the wife batterers, respectively. The seriousness of the violence within the gay relationship was likewise perceived as falling in between the husband/wife and wife/husband scenarios. However, 
this was not the trend throughout the measures. Interestingly, participants disliked the batterer in the gay scenario nearly as much as the heterosexual male aggressor but disliked the gay victim more than either the heterosexual male or female victim. Participants also perceived the gay battering to be less violent than either the husband batterer or wife batterer scenario. In addition, participants felt more strongly that the gay victim should leave their partner than either the husband or wife victims.

The implications of these results may give further insight to the perception of a gay male victim of domestic violence. One such implication is indicated in the ratings that place both the gay victim and batterer between the husband and wife counterparts. This is consistent with research that demonstrates that people tend to view gay males as more effeminate than heterosexual men, yet not as feminine as heterosexual women. In addition, the battering was seen as less violent, supporting the claim that there is a perception that both partners were more equally responsible for the violence than either of the heterosexual couples. The results also indicate that the gay partners were disliked more than the heterosexual partners, which may, in part, explain why participants believed the gay male victim should leave the batterer more readily than the heterosexual victims.

Results such as these might occur for many reasons, including the general disapproval of gay couples or the belief that the abuse was mutually combative. Whatever may be the cause there is apparently a clear disjunction between perceived responsibility of the victim and their likeability, based on sexual orientation. 
One possible explanation for these findings may be that within the context of the gay male partnership, the batterer's occupation was that of a sales representative of a local furniture store, while the victim's occupation was described as an interior designer. Thus, the perception of the victim may have been buffered because it is consistent with the stereotype of a gay male. The victim within this scenario is arguably the more stereotypically feminine gay male, whereas the batterer was the more masculine of the couple. This scenario fits with what would be the stereotypical husband-batterer, wifevictim dyad. However, if these roles were reversed and the stereotype violated, it may be the case that the masculine victim would be evaluated more negatively than by observers. Specifically, because the more masculine partner may be perceived as being able to defend himself, participants may attribute more blame to him than a more feminine victim. Given this possibility, the extent to which one is consistent with the stereotype of victims and perpetrators of domestic violence, may have implications for the legitimacy of claims for same-sex domestic violence.

\section{Stereotypes Based on Attractiveness}

Stereotypes have been shown to be short-cuts in determining what characteristics a person is believed to possess (Hilton \& von Hipple, 1990). However, another factor relating to appearance may also contribute to categorizing individuals: attractiveness. Research has shown that there are benefits associated with being physically attractive, that "what is beautiful is good," (Darby \& Jeffers, 1988). In other words, when attributions are made about a person, the more attractive the person is viewed as, the more positive the attributions will be towards him or her. Within the context of a 
courtroom, the implication is that a more attractive defendant would be seen as less likely to commit the crime or receiving a less severe sentence.

In a courtroom setting, physically attractive defendants are perceived as less responsible for their crimes, less likely to be convicted and are sentences to less severe punishment, (Efran, 1974; Stewart, 1980, 1985; Darby \& Jeffers, 1988). Field studies have found that attractiveness plays a role in real courtrooms. Data indicates that not only were unattractive defendants found guilty more frequently than attractive defendants, but they were given harsher sentences and viewed as a more stereotypical criminal and more likely to commit another crime (Stewart, 1980; Hoffman, 1981). However, there are some limitations to this type of research, including controlling levels of attractiveness and type of crime committed. To better explore how perceptions of attractiveness do influence individuals within the context of courtroom, experimental researchers look to mock-trials.

In a mock-jury simulation, Efran (1974) asked participants to read a judicial case and then presented them with a photograph of either an attractive or unattractive defendant. The participants judged the defendant's innocence, and if judged guilty, rated how severe punishment should be. Results showed that physically attractive defendants were found guilty less often than the unattractive defendants. In addition, the unattractive defendants were sentenced more severely and with more participant certainty than the attractive defendants. In other words, when the participants found the attractive defendant guilty, they felt less confident about their decision. 
Taken together, attractiveness has been found to be a key element in creating perceptions of individuals in the context of a courtroom. Similarly, attractiveness has also been linked with perceptions of sexuality. Specifically, unattractive women are more likely to be viewed as homosexual and conversely lesbians are perceived as less attractive (Dew, 1985). This incorrect stereotype could place lesbians at yet another disadvantage when combined with involvement in a domestic abuse situation. 


\section{CHAPTER II}

\section{PURPOSE}

Gender-based stereotypes guide expectations for the behavior of men and women and further define their roles within intimate relationships (Corley \& Pollack, 1996). Lesbians however are perceived as violating gender-based stereotypes for women and are rather viewed as masculine in appearance and behavior (Kite \& Deaux, 1987). Moreover, within lesbian partnerships, gender-based stereotypes support heterosexist assumptions wherein one partner is perceived as dominant (masculine) and the other as submissive (feminine). Taken together, these stereotypes may have implications for the legitimacy with which claims of domestic violence advanced by lesbians are perceived. Because perceptions of victims of domestic violence contain one set of expected behaviors and characteristics (i.e., feminine) violations of these expectations may undermine clams of domestic violence advanced by lesbians. In light of evidence suggesting that violence between lesbian couples is often times dismissed or viewed as "mutually combative," (Marrujo \& Kreger, 1996) closer examination of expectations that support these perceptions was warranted.

To this end, participants read a scenario that depicts a working couple who had a dispute about having leftovers for dinner. The argument escalated into physical violence and ends with an encounter with the police. Using this scenario, this study examined perceptions of lesbian victims of domestic violence who are gender stereotype consistent 
(feminine in appearance) versus inconsistent (masculine in appearance). Furthermore, the gender stereotype consistency of the perpetrator was likewise varied such that she appears to be consistent (masculine in appearance) versus inconsistent (feminine in appearance).

It was anticipated that the victim who was masculine in appearance would be perceived as more blameworthy and responsible for the abuse than the feminine appearing victim. This was particularly likely to be the case when the perpetrator was feminine in appearance. Likewise, it was anticipated that the masculine appearing perpetrator would be seen as more aggressive and held more accountable for the abuse than the feminine appearing perpetrator. Again, it was expected that this will likely be especially true when the victim was feminine in appearance. In situations where the perpetrator and the victim were equated in terms of their masculine/feminine appearance, claims of assault were likely to be negated and rather perceived as a mutually combative incident. 


\section{CHAPTER III}

\section{EXPERIMENT 1: PHOTOGRAPH VALIDATION}

\section{Method}

\section{Participants}

43 undergraduate psychology students from the University of North Dakota signed-up to participate in order to fulfill a course requirement or for extra credit in their course.

\section{Materials}

Participants viewed a power-point presentation containing eight photographs (Appendix A). Photographs were acquired from www.hotornot.com, a website in which women and men submit their picture to be rated on attractiveness by anyone who accesses the public site. The eight women in the pictures were equated on attractiveness by over 1000 people who accessed the sight.

\section{Questionnaires}

\section{Attribution of Characteristics Scale}

Participants were asked to respond to 12 items ranging from 0 (not very likely) to 5 (very likely), indicating the likelihood to which they believed the target possessed particular attributes. This attribute measure was derived from Deaux and Lewis (1983) and included masculine and feminine traits (e.g., independent, emotional) masculine and 
feminine role behaviors (e.g., financial provider, takes care of home) and masculine and feminine occupations (e.g., engineer, nurse worker, telephone operator).

Based on theoretical and empirical justification (Deaux \& Lewis, 1983) items were separated into three component parts: traits, roles and occupation. Two items tapping into each of these three components were categorized according to masculine traits: competitive and independent, roles: financial provider and head of the household, and occupation: auto mechanic and engineer, versus feminine traits: warm and emotional, roles: does the laundry and tends to the house, and occupation: secretary and nurse, with higher scores reflecting masculine characteristics. Four photos were chosen on the basis of extreme means on these combined components.

\section{Perceptions of Attractiveness}

Participants were asked to respond on a 5-point scale, 1 (not very attractive) to 5 (very attractive), the extent to which they perceived each of the eight targets to be attractive. (Appendix B).

\section{Procedure}

Participants participated in experimental sessions in groups of 3-13, and were instructed that the experimenter was interested in characteristics that they associated with different individuals. Following the completion of the consent form, (Appendix C), they were shown a collection of eight pictures of female targets and asked to respond to the Atribute and Manipulation Check scales. Photographs were counterbalanced in order to minimize order effects. When all participants had completed the questionnaire, they were 
debriefed orally as well as in written format (Appendix D), thanked for their time and dismissed.

\section{Results \\ Attribution of Characteristics Scale}

Target pictures were selected on the basis of the combined extreme scores on traits, roles and occupation, with higher scores reflecting masculine characteristics. Targets 5 and 3 were selected as the primary masculine and feminine targets, respectively. Targets 2 and 7 were selected to act as the secondary picture in the Masculine-Masculire and Feminine-Feminine conditions, respectively. Table one represents relevant means.

\section{Perceptions of Attractiveness}

For the two items relating to attractiveness and likeability, a mean response on attractiveness was generated. A within-subject analysis was conducted across each of the eight photos to determine if the photos were equated, to the extent that it was possible, on the participants perception of the targets attractiveness. There were no significant differences, $F(1,42)=3.10, p>.05$. Table 2 presents relevant means. 


\section{CHAPTER IV}

\section{EXPERIMENT 2}

\section{Method}

\section{Participants}

287 undergraduate psychology students $(m e n=101$; women $=186)$ from the University of North Dakota were asked to participate in a study examining people's perceptions of violence. Participants were given credit in order to fulfill a course requirement or for extra credit.

\section{Materials}

ignettes

Participants received a written vignette regarding a domestic violence scenario. The scenario was adapted from the vignette used in Harris and Cooke's (1994) study (see Appendix E). This vignette described a situation in which a woman verbally and then physically assaults her partner.

\section{Photographs}

Participants viewed two pictures in Power-Point format, one of the alleged victim and one of the accused batterer. The two most extreme pictures varied in appearance defined as masculine or feminine by a different set of participants from Experiment 1. 


\section{Questionnaires}

Perception of Violence

Participants were asked to respond to a questionnaire using a five-point Likert scale with endpoints defined by the wording of the item (i.e.. not serious-very serious; not violent-very violent). The 20 items on this questionnaire tapped into seven measures reflecting perceptions of the incident. Specifically, these measures reflected the perceptions of the dangerousness of the situation, the plausibility of the claim and Blameworthiness of the victim and the offender. (Appendix. G)

Dangerousness of the Situation: Ratings of the extent to which the participants perceived the incident as dangerous, consisted of participant's mean response on four items ( $\propto=0.75$ ), assessing how serious, severe, and violent the incident was and, the likelihood that the respondent would have contacted the police if they themselves witnessed the incident. Higher scores reflected higher per'sentage of dangerousness.

Plausibility of the Claim: Ratings of the extent to which the participants perceived the incident as plausible consisted with participants mean response on two items $(r=55)$ evaluating the extent to which they perceive the incident as probable and realistic. Higher scores reflect higher perception of the incident seen as plausible.

Alleged Victim's Blameworthiness: Evaluation of the alleged victim's level of blame for the event consisted of participants' responses assessing the degree to which the alleged victim's should be blamed for the incident of abuse. Higher scores reflect more blamed assigned to the victim. 
Accused Blameworthiness: Evaluation of the accused level of blame for the event consisted of participants' responses assessing the degree to which the accused should be blamed for the incident of abuse. Higher scores refiect more blamed assigned to the victim.

\section{Perceptions of Attractiveness}

Participants were asked to respond on a 5-point scale ranging from 0 (not at all) to 5 (very much), the extent to which they perceived both the alleged victim and the accused to be attractive.

\section{Procedure}

Participants who consented to participate (Appendix $\mathrm{H}$ ) were randomly assigned to one of the five domestic violence batterer-victim conditions: Masculine VictimFeminine Batterer, Masculine Victim-Masculine Batterer, Feminine Victim-Feminine Batterer, Feminine Victim-Masculine Batterer and No Picture control, and asked to read the appropriate police report regarding a dorıestic violence incident. Participants were provided with photos of the victim and batterer (with the exception of the control group) and asked to fill out the Perceptions of Violence and the Perceptions of Attractiveness questionnaires. When participants had completed the questionnaires, they were debriefed orally (Appendix I) as well as in written format, thanked for their time and dismissed. 


\section{CHAPTER V}

\section{RESULTS}

\section{Perceptions of Violence Questionnaire}

\section{Dangerousness of the Situation}

A. 2 (Victim: Masculinity vs. Femininity) x 2 (Offender: Masculinity vs.

Femininity) x 2 (Participant Gender) analysis of variance (ANOVA) revealed a significant main effect for gender $F(1,229)=18.93, p<.05, \eta^{2}=.03$, such that women $(M=$ 3.67, $S D=.72)$ rated the incident as more dangerous than men $(M=3.29, S D=.79)$.

Plausibility of the Cixim

A 2 (Victim) $\times 2$ (Offender) $\times 2$ (Participant Gender) ANOVA revealed a three-way interaction of victim characterization, offender characterization and gender $F(1$, 269) $=13.12, p<.05 \eta^{2}=.04$. This interaction was broken down into two-way interactions between victim characterization and offender characterization as a function of gender. Only the two-way interaction for women attained significance, $F(1,150)=10.29, p<.05$ $\eta^{2}=.06 .($ See Figure 1)

Simple main effects of offender characterization at each level of victim characterization revealed significance for both the masculine appearing victim, $F(1,150)$ $=6.83, p<.05$, and the feminine appearing victim, $F(1,150)=5.68, p<.05$. The masculine appearing victim was viewed by female participants as having a more 
plausible claim when the offender was characterized as feminine $(M=3.80, S D=.73)$ than when the offender was characterized as masculine $(M=3.22, S D=1.10)$. Conversely, female participants rated the feminine appearing victim as having a more plausible claim when the offender was characterized as masculine $(M=3.93, S D=1.03)$ than when the offender was characterized as feminine $(M=3.36, S D=1.13)$.

Simple main effects of victim characterization at each level of offender characterization revealed significance for the masculine appearing offender, $F(1$, $150)=7.99, p<.05$. When the offender was masculine in appearance, female participants viewed the victim as having a more plausible claim when she was characterized as feminine $(M=3.93, S D=1.02)$ than when she was characterized as masculine $(M=3.23$, $S D=1.10)$

Alleged Victim's Blameworthiness

A 2 (Victim) $\times 2$ (Offender) $\times 2$ (Participant Gender) ANOVA revealed a significant main effect for victim $F(1,266)=5.41, p<.05, \eta^{2}=.022$. The feminine appearing victim $(M=.77, S D=1.26)$ was blamed less than the masculine appearing victim $(M=1.16, S D=1.28)$.

Accused Blameworthiness

A 2 (Victim) $\times 2$ (Offender) $\times 2$ (Participant Gender) ANOVA revealed an interaction of offender by gender $F(1,276)=6.23, p<.05, \eta^{2}=.022$. Simple main effect of offender characterization at each level of gender revealed significance only for female participants $F(1,181)=4.55, p<.05$. The feminine appearing offender $(M=4.18, S D=.99)$ 
was rated by female participants as more to blame than the masculine appearing offender $(M=4.04, S D=1.14), t(154)=1.34, p<.05$. (See Figure 2$)$

Simple main effects of gender at each level of offender characterization revealed significance for the feminine appearing offender, $F(1,152)=5.99, p<.05$. Female participants rated the offender as more to blame when she was characterized as feminine in appearance $(M=4.18, S D=.99)$ than the masculine appearing offender $(M=4.04$, $S D=1.14)$.

Perceptions of Attractiveness of Alleged Victim

A 2 (Victim) $\times 2$ (Offender) $\times 2$ (Participant Gender) revealed a significant main effect for gender $F(1,221)=7.88, p<.05, \eta^{2}=.034$ such that female participants $(M=2.31$, $S D=1.18)$ rated the alleged victim as more attractive than men $(M=1.92, S D=1.16)$.

A simple main effect for was also found for victim $F(1,221)=21.98, p<.05$, $\eta^{2}=.090$, such that the feminine appearing victim $(M=2.61, S D=1.15)$ was perceived as more attractive than the masculine appearing victim $(M=1.79, S D=1.0 \%)$.

Perceptions of Attractiveness of Accused

\section{A 2 (Victim) $\times 2$ (Offender) $\times 2$ (Participant Gender) ANOVA revealed a} significant main effect for offender $F(1,221)=73.4, p<.05, \eta^{2}=.249$, such that the feminine appearing offender $(M=2.75, S D=1.11)$ was perceived as more attractive than the masculine appearing offender $(M=1.44, S D=1.07)$. 


\section{CHAPTER VI}

\section{DISCUSSION}

Gender-based stereotypes guide expectations for the behavior of men and women and further define their roles within intimate relationships (Corley \& Pollack, 1996). Lesbians, however, are perceived as violating gender-based stereotypes for women and are viewed as masculine in appearance and behavior (Kite \& Deaux, 1987). Within lesbian partnerships, gender-based stereotypes risk supporting heterosexist assumptions wherein one partner is perceived as aggressive (masculine) and the other as submissive (feminine). Taken together, these stereotypes may have implications for the legitimacy with which claims of domestic violence advanced by lesbians are perceived. To this end, the present study evaluated the impact of gender-based stereotypes within the context of a lesbian domestic violence scenario. More specifically, this study examined the extent to which the alleged victin would be blamed for her own abuse when she was characterized as either masculine or feminine in appearance and the degree to which these perceptions would be influenced by the masculine or feminine appearance of the offender.

Overall, results suggest that perceptions of victims of domestic violence contain a set of expected behaviors and characteristics (i.e., feminine) that are pervasive in the context of lesbian relationships. However, these beliefs appear to be mitigated not only by the gender characterization of the offender and victim, but the gender of the observer as well. 
One of the most consistent findings in the present study concerned the characterization of the victim. Specifically, in regards to level of blame, the feminine appearing victim was seen as less blameworthy than the masculine characterized victim. This result is not surprising in light of the gender-based stereotypes that support that men and in turn, masculine characterized individuals, are supposed to be stronger and more aggressive than women or feminine characterized individuals (Corley \& Pollack, 1996) Consequently, masculine individuals are perceived as being able to protect themselves in an attack. The masculine appearing victim was violating this stereotype and therefore was perceived as more blameworthy.

The masculine appearing victim was not only seen as more to blame for her own abuse, but was also viewed as less attractive. Although the targets in this study were originally rated equally on attractiveness prior to the start of study, the target characterized as masculine was viewed as less attractive after being labeled as either a lesbian or a victim. One reason for this result could be that the masculine appearing women violated societal norms. By being labeled as a victim, she was thus viewed as less attractive. In a similar vein, participants may have attributed unattractive characteristics, such as weakness or passivity, to the masculine victim. Research has shown that behaviors and attractiveness are in fact linked (Efran, 1974; Stewart, 1980, 1985; Darby \& Jeffers, 1988) and that the level of one can influence the level of the other. In other words, a physically attractive person who is engaging in a behavior that is unappealing can appear less attractive. Conversely, an unattractive person may be viewed as engaging in unappealing behaviors. One implication of this finding is that 
unattractive victims of actual domestic violence may be perceived as less. Future research examining the impact of attractiveness on claims of victimization would be helpful in the regard.

The characterization of the victim in conjunction with who her abuser was, also had an impact on how she was perceived. This was demonstrated most significantly when considering the plausibility of the claim. Surprisingly, the masculine victim was viewed as having a more plausible claim by women when the offender was characterized as feminine. It may be the case that female participants perceived the feminine appearing offender as violating gender-based norms prescribing appropriate (i.e. non-aggressive) behavior for women to a greater degree than the masculine appearing offender and were thus more sympathetic to the claims advanced by the masculine victim. At the same time, however, female participants viewed the feminine appearing victim as having a more legitimate claim when the offender was characterized as masculine. Again, as gender-based sterectypes characterize intimate relationships in heterosexist terms, such that the passive role is assigned to the women and the aggressive role is assigned to men, it may be the case that this scenario was viewed by female participants as most consistent with gender-based norms. Indeed, overall, women viewed the victim as having a more legitimate claim when the offender was characterized as masculine. Beliefs such as these serve only to perpetuate the heterosexual definition of a relationship and dismiss any victim's claim of abuse in a relationship that does not fit this ideal. Future research examining the impact of adherence to gender-role ideology would be helpful in terms of 
delineating the impact of attitudes toward women on perceptions of violerice within lesbian relationships.

Finally, victim and offender characterizations were not the only contributing factors when considering perceptions of lesbian domestic violence. Gender also played an important role in how these women were viewed. The perceived level of danger in this domestic violence scenario demonstrated a clear case of this gender difference. Female participants tended to rate the incident as more dangerous than male participants. This has been found to be due, in part, to the more prevalent threat that all women face in regards to becoming a victim of domestic violence (Pitt, 2000). It may be the case that for women, the plight of the battered woman is more real, whereas for men, the perceived threat of being battered is minimal. Thus, although the violence was taking place in a lesbian partnership, women were nonetheless more likely than men to rate the violence as more dangerous. It appears then, that women are better able to appreciate the serious nature of domestic violence irrespective of the characterization of the victim or offender.

Gender also played a role in the degree to which the offender was blamed for the incident. Specifically, female participants blamed the feminine characterized offender more for the incident than the masculine characterized offender. Blaming the feminine appearing offender more may be again, due to the fact that she was perceived as violating the traditional gender-based expectations for women in general (i.e., by being aggressive). Previous research has found that women who are seen as aggressive are liked less and therefore, blamed more for the abuse (Terrance, 2000). Women may be especially sensitive to this belief and may resort to other justifications for the abuse when 
perpetrated by a characteristically feminine offender as opposed to a masculine offender. Research has shown that when a woman violates the traditional gender-role, she is perceived as less mentally healthy and stable but more confused (Storms et al. 1981). Among women it may be that the justification for a masculine offender is that she is aiready perceived as aggressive and dominant. For a feminine appearing offender, that justification does not work, and therefore there must be something about the offender that makes her more blameworthy.

Further exploration of factors that influence victim blame and perceptions of lesbian domestic violence is still necessary. A future direction from this study could include evaluating participants pre-existing stereotypes of lesbians. An additional direction for future research would be exploration of the perceptions of lesbian domestic violence within a community of gay and lesbian people. Although this study's participant pool consisted of mostly self-proclaimed heterosexuals $(\mathrm{N}=281)$, it would be beneficial to study the community in which this violence occurs. The implication being that ofter times lesbians will seek out other lesbians and gay-friendly organizations for help. One cannot assume that these resources would be stereotype-free. However, further research can lead to better education and consequently better resources for all victims of domestic violence. 


\section{Conclusion}

As with any research, methodological limitations should be noted. Although to date, no similar studies have been conducted, the use of pictures may be a confounding variable. Although measures were employed, such as each having over 1000 independent ratings, to help reduce effects, there is no doubt that attractiveness can play a role in perceptions of guilt (Efran, 1974; Stewart, 1980, 1985; Darby \& Jeffers, 1988). Despite the fact that the photographs were rated independently and not within the context of a lesbian domestic violence scenario, these photographs were not identical in features common to physical attractiveness, such as symmetry. These were photographs of real women, not computer generated, and therefore all confounds could not be eliminated.

In addition to this limitation, as in similarly conducted studies (Harris \& Cooke, 1994), the artificial nature of the task may limit the external validity of the findings. However, research using vignettes has been found to correlate with field studies, in regards to evaluating guilt and blame in a courtroom setting (Stewart, 1980, 1985; Hoffman, 1981). No such studies could be found looking at these factors in a community agency setting. Nevertheless, a more diverse cross-section of the population with demographic characteristics consistent with that of actual members of the community, community agency employees and others that may be asked to evaluate claims of domestic violence, may contribute to the ability to generalize the findings.

Despite these problems, this study did support that heterosexually-based genderexpectations can influence the credibility of a victim of lesbian domestic violence. These stereotypes may have implications for the legitimacy with which claims of 
domestic violence advanced by lesbians are perceived. These expectations may undermine claims of domestic violence advanced by lesbians, therefore limiting the resources that may be offered to a lesbian victim of domestic violence.

Table 1. Means and Standard Deviations for Target Pictures as a Function of Combined Attributions of Characteristics

\begin{tabular}{lclll} 
Target Picture & Overall Mean (SD) & Traits (SD) & Roles(SD) & Occupation(SD) \\
\hline Target 1 & $2.22(.48)$ & $3.51(.41)$ & $3.24(.85)$ & $2.15(.66)$ \\
Target 2 & $2.40(.43)$ & $3.48(.63)$ & $2.64(.84)$ & $2.23(.80)$ \\
Target 3 & $1.71(.53)$ & $3.21(.57)$ & $3.20(.77)$ & $2.21(.78)$ \\
Target 4 & $2.01(.58)$ & $3.29(.62)$ & $3.17(.68)$ & $2.20(.83)$ \\
Target 5 & $2.77(.45)$ & $3.03(.54)$ & $2.29(1.06)$ & $2.01(.88)$ \\
Target 6 & $2.34(.58)$ & $3.40(.61)$ & $3.40(.69)$ & $2.35(.77)$ \\
Target 7 & $1.95(.45)$ & $2.89(.72)$ & $1.93(1.05)$ & $1.52(.80)$ \\
Target 8 & $2.35(.44)$ & $3.52(.54)$ & $3.30(.61)$ & $2.27(.62)$
\end{tabular}

Note: Potential range of response $=0$ (Not Very Likely) to 5 (Very Likely) 
Table 2. Means and Standard Deviations for Target Pictures as a Function of Attractiveness

Target Picture Overall Mean (SD)

$\begin{array}{ll}\text { Target } 1 & 3.26(1.05) \\ \text { Target 2 } & 2.74(.95) \\ \text { Target } 3 & 2.77(1.25) \\ \text { Target } 4 & 3.33(.99) \\ \text { Target } 5 & 1.61(1.14) \\ \text { Target 6 } & 1.88(1.07) \\ \text { Target } 7 & 3.60(1.14) \\ \text { Target } 8 & 3.70(.9342)\end{array}$

Note: Potential range of response $=0$ (Not at all Attractive) to 5 (Very Attractive) 
Table 3. Means and Standard Deviations for Plausibility of the Claim

\begin{tabular}{ll} 
MEN & Mean (SD) \\
\hline Victim-Offender Characterization & $3.20(1.19)$ \\
\hline Masculine-Feminine & $3.77(.75)$ \\
Masculine-Masculine & $2.84(1.10)$ \\
Feminine-Masculine & $3.21(.98)$ \\
Feminine-Feminine & \\
\hline & \\
WOMEN & Mean (SD) \\
Victim-Offender Characterization & $3.80(.73)$ \\
\hline Masculine-Feminine & $3.22(1.10)$ \\
Masculine-Masculine & $3.93(1.02)$ \\
Feminine-Masculine & $3.36(1.13)$ \\
\hline
\end{tabular}

Note: Potential range of response $=0$ (Not at all Attractive) to 5 (Very Attractive) 


\section{Female Participants Rating}

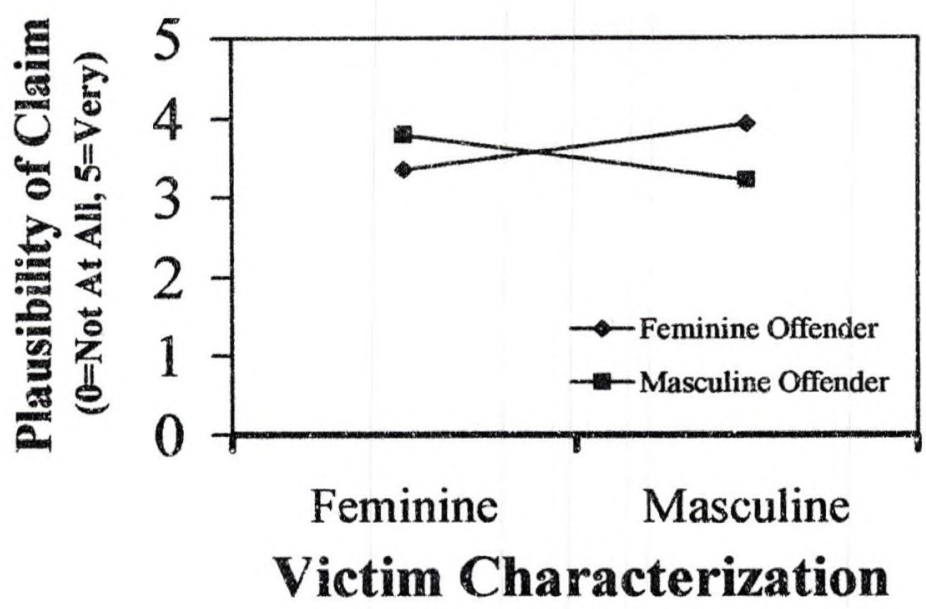

\section{Male Participants Rating}

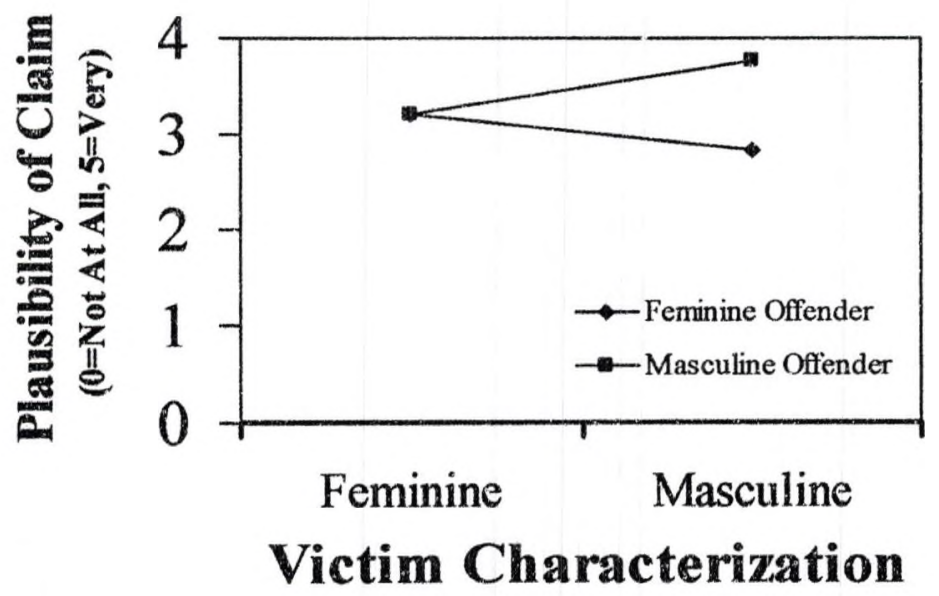

Figure 1. Means for Victim Plausibility of Claim 


\section{Accused Blameworthiness}

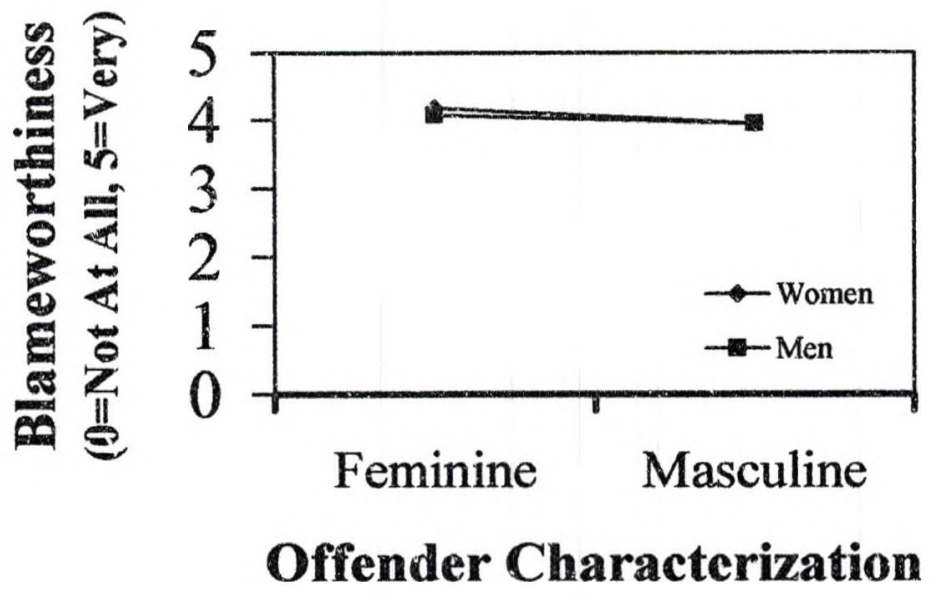

Figure 2. Means for Accused Blameworthiness 


\section{APPENDIX A \\ PHOTOGRAPHS}

Masculine Characterized

Feminine Characterized
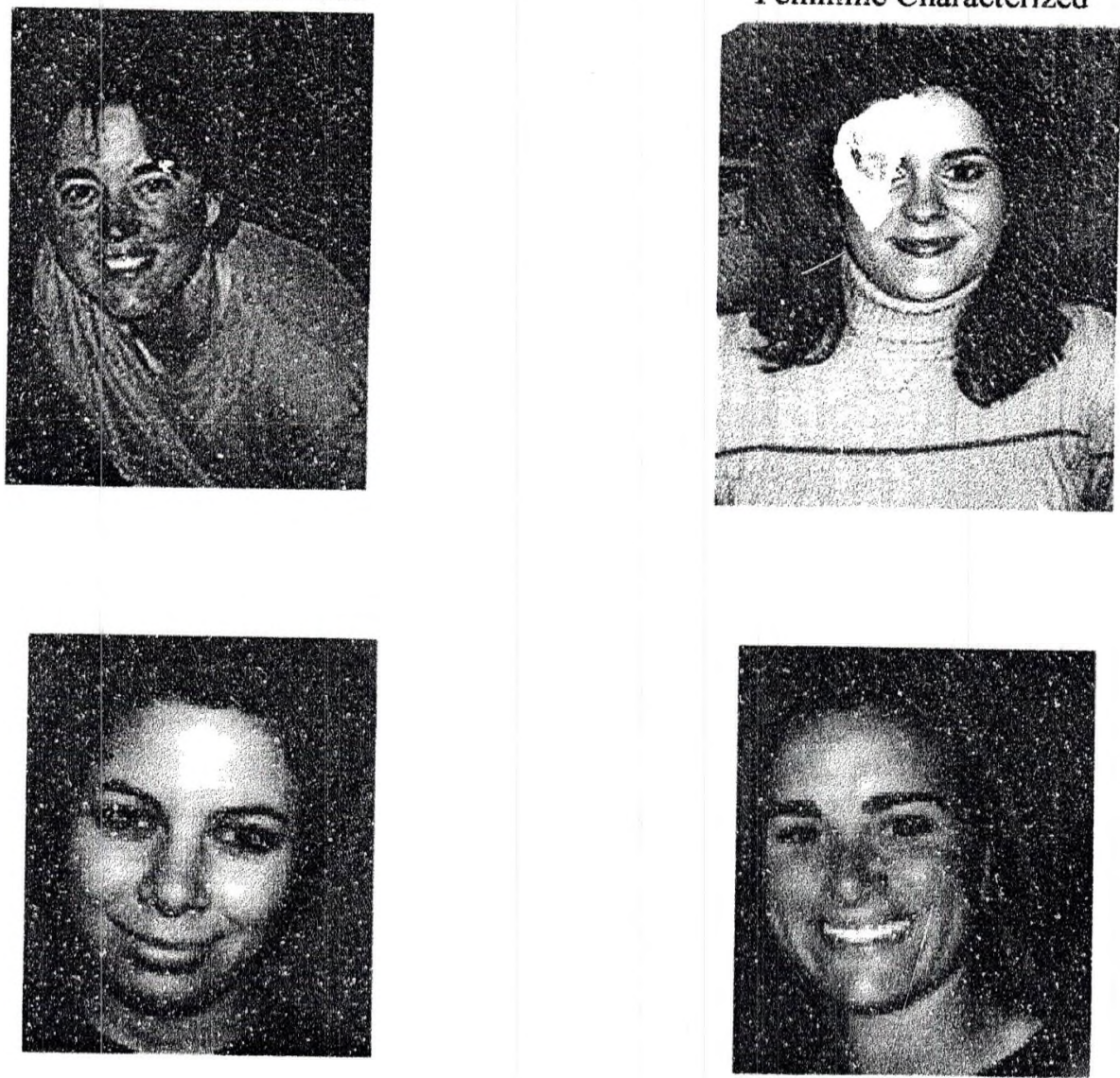


\section{APPENDIX b \\ ATTRIBUTIONS OF CHARACTERISTICS SCALE}

Gender: Male Female

Age:

Please read each statement and choose the one most appropriate response to each statement: 0 (Not Very Likely) to 5 (Very Likely).

1. What is the probability that she tends to the house?

$\begin{array}{llllcc}0 & 1 & 2 & 3 & 4 & 5 \\ \text { Not very } & & & & & \text { Very } \\ \text { Likely } & & & & & \text { Likely }\end{array}$

2. What is the probability that she is the financial provider?

$\begin{array}{llllcc}0 & 1 & 2 & 3 & 4 & 5 \\ \text { Not very } & & & & & \text { Very } \\ \text { Likely } & & & & & \text { Likely }\end{array}$

3. What is the probability that she is an auto mechanic?

$\begin{array}{lllccc}0 & 1 & 2 & 3 & 4 & 5 \\ \text { Not very } & & & & & \text { Very } \\ \text { Likely } & & & & & \text { Likely }\end{array}$

4. What is the probability that she is independent?

$\begin{array}{llllcc}0 & 1 & 2 & 3 & 4 & 5 \\ \text { Not very } & & & & & \text { Very } \\ \text { Likely } & & & & & \text { Likely }\end{array}$

5. What is the probability that she is a nurse?

$\begin{array}{llllcc}0 & 1 & 2 & 3 & 4 & 5 \\ \text { Not very } & & & & & \text { Very } \\ \text { Likely } & & & & & \text { Likely }\end{array}$

6. What is the probability that she is emotional?

$\begin{array}{llllcc}0 & 1 & 2 & 3 & 4 & 5 \\ \text { Not very } & & & & & \text { Very } \\ \text { Likely } & & & & & \text { Likely }\end{array}$


7. What is the probability that she takes is the head of the household?

$\begin{array}{lllllc}0 & 1 & 2 & 3 & 4 & 5 \\ \text { Not very } & & & & & \text { Very } \\ \text { Likely } & & & & & \text { Likely }\end{array}$

8. What is the probability that she is does the laundry?

$\begin{array}{llllcc}0 & 1 & 2 & 3 & 4 & 5 \\ \begin{array}{l}\text { Not very } \\ \text { Likely }\end{array} & & & & & \text { Very } \\ \text { Likely }\end{array}$

9. What is the probability that she is an engineer?

$\begin{array}{llllcc}0 & 1 & 2 & 3 & 4 & 5 \\ \begin{array}{l}\text { Not very } \\ \text { Likely }\end{array} & & & & & \text { Very } \\ \text { Likely }\end{array}$

10. What is the probability that she is warm?

$\begin{array}{llllcc}0 & 1 & 2 & 3 & 4 & 5 \\ \text { Not very } & & & & & \text { Very } \\ \text { Likely } & & & & & \text { Likely }\end{array}$

11. What is the probability that she is competitive?

$\begin{array}{llllcc}0 & 1 & 2 & 3 & 4 & 5 \\ \begin{array}{l}\text { Not very } \\ \text { Likely }\end{array} & & & & & \text { Very } \\ \text { Likely }\end{array}$

12. What is the probability that she is a secretary?
$\begin{array}{ll}0 & 1\end{array}$
2
3
Not very
Likely

13. What is the likelihood that she prefers to be with men?

$\begin{array}{llllcc}0 & 1 & 2 & 3 & 4 & 5 \\ \begin{array}{l}\text { Not very } \\ \text { Likely }\end{array} & & & & & \text { Very } \\ \text { Likely }\end{array}$


14. What is the likelihood that she is prefers to be with women?

$\begin{array}{llllcc}0 & 1 & 2 & 3 & 4 & 5 \\ \begin{array}{l}\text { Not very } \\ \text { Likely }\end{array} & & & & & \begin{array}{c}\text { Very } \\ \text { Likely }\end{array}\end{array}$

15. What is the likelihood that you would be friends with her?

$\begin{array}{llllcc}0 & 1 & 2 & 3 & 4 & 5 \\ \begin{array}{l}\text { Not very } \\ \text { Likely }\end{array} & & & & & \text { Very } \\ \text { Likely }\end{array}$

16. How attractive is she?

$\begin{array}{lllllc}0 & 1 & 2 & 3 & 4 & 5 \\ \text { Not very } & & & & & \text { Very }\end{array}$




\section{APPENDIX C \\ INFORMED CONSENT FORM \\ PERCEPTIONS OF PHYSICAL APPEARANCE}

My name is Betsi Little, and I am a graduate student in the Department of Psychology at the University of North Dakota, and I am working on a research project to examine people's perceptions of physical appearance. This study will take approximately 45 minutes to an hour to complete.

You are invited to participate in a study in which you will be asked to view six pictures and then to respond to several questions that are designed to assess your opinions concerning the roles, traits and occupation of those pictured. This information will be used in a later study that is looking at the perceptions of relationships.

The benefits from this research will be a better understanding of how people perceive relationships. Specific benefits to you for your participation will be a better understanding of what psychological research is about, and the opportunity to earn extra credit in your current psychology class. Some people may find the issue of domestic assault to be offensive and upsetting therefore, you are under no obligation to continue with the study. Contact numbers for agencies will be provided at the end of the study for follow-up care if desired. Service listed are free of charge. Any charges for services that may arise, are the responsibility of the participant.

Some participants may feel a little apprehensive because this is an evaluative situation, or may feel anxious responding to questions pertaining to personally sensitive issues. You do not have to respond to any questions that you do not want to, and all data will remain confidential and anonymous with respect to your personal identity. To insure privacy concerns, participants will be given numerical identification numbers for processing the data and your names will not be revealed in presentation or publication of the study.

Questionnaires will be stored separately from consent forms in a locked cabinet in CorwinLarimore 115 for a period of three years.

Participation is voluntary. Your decision whether or not to participate will not affect your future relations with UND. If you decide to participate, you are free to discontinue participation at any time without prejudice. If you have any questions about this research, you may ask Betsi Little at 777-8805. Alternatively, you may contact the Thesis Committee Chair for this study, Dr. Cheryl Terrance at 777-3921.

If you have any other questions or concerns, please call the Office of Research and Program Development at 777-4279.

I have read all of the above and willingly agree to participate in this study.

Participants Name:

Date:

Witness's Narne:

Date: 


\section{APPENDIX D \\ DEBREIFING INFORMATION}

I would like to thank you for participating in this study. Your participation will help us understand more about peoples perceptions about a person based on their physical appearance.

The purpose of the study in which you have participated was to investigate the influence of physical appearance on perceived roles, traits and occupations. Specifically, I am investigating characteristics that are stereotypically masculine or feminine beigh assigned to a target based on her appearance. The results of this study will be used in another study looking at domestic violence within a same-sex couples.

I appreciate your taking the time to answer the questions and want to stress that all of your answers are valuable. I understand that the questions may be upsetting and anxiety provoking for some people and I stress that you contact myself or one of the agencies listed below if you have any concerns regarding this study or the issues referred to in this study. The list of contacts includes agencies within both the university and the community that are available for men and women. Services listed are free of charge. Any charges for services that may arise, are the responsibility of the participant.

Due to the nature of this research, I ask that you do not discuss this study with potential participants until testing is complete (approximately December of 2003). If you wish to discuss any additional aspects of the research, I am available for appointments.

If you have any questions regarding this experiment, you may contact Betsi Little in Corwin-Larimore 115 or by phoning $777-8805$.

\section{Contact Information}

Police Phone Numbers

Emergency 911

Grand Forks $\quad 787-8000$

Crisis Intervention

Crisis Intervention Help-Line 1-800-472-2911

Northeast Human Services Crisis Line 775-0525

Abuse and Rape Crisis Line $\quad 746-8900$

Altru Health System $\quad 780-5900$

Support Services

Community Violence Intervention Center $\quad 746-8900$

Grand Forks County Family Services $\quad 787-8540$

Catholic Family Services $\quad 775-4196$

Lutheran Social Services $\quad 772-4418$

Counseling Services

UND Counseling Center

$777-2127$ 


\section{APPENDIX E}

VIGNETTE

\section{THE DAILY HERALD}

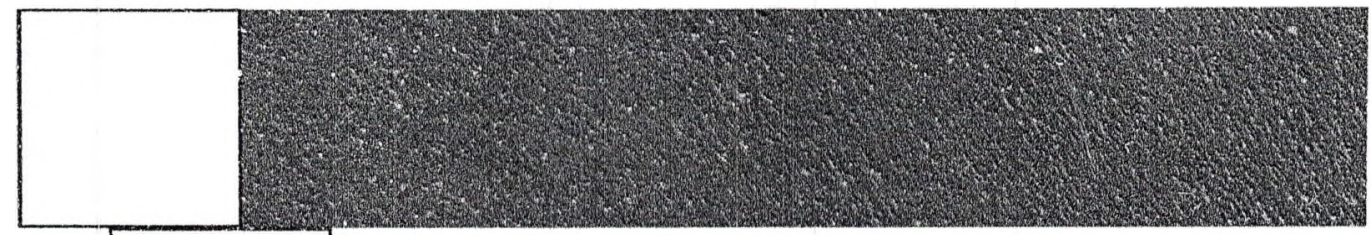

Domestic Assault Investigation

By Cathy Coombs

Daily Herald Staff Writer

KANSAS CITY, January 18, 2001-

Two police officers responded to an anonymous telephone call reporting the occurrence of a domestic dispute. Upon arriving at the location of the reported dispute, which appeared to have ended, the officers conducted interviews with Tina Crosby (insert occupation) and her partner Julie Lane (insert occupation). According to Officer Kevin Smith, of the Kansas City Police Department, he and another officer found Ms. Lane on the living room couch bleeding and with a black eye.

According to Lane, she returned home from work earlier that evening at 6:15 p.m., 45 minutes later than usual. As she was late, She decided to prepare leftovers from the previous night for dinner. After placing the food in the oven, she sat down to watch the news on the television. About 10 minutes later, Crosby arrived home from work and asked her partner what was being prepared that evening. In response, Lane explained that, as she was late coming home from work, she was preparing leftovers. Upon hearing this, Crosby became upset and angry. She argued that, as Lane had time to watch the news, she should have time to make a proper dinner. She then yelled that since she had things to do, she should make sure she gets home on time. Lane then went into the kitchen to prepare dinner. Crosby followed her into the kitchen. She grabbed Lane by the arm and slapped her, knocking her to the floor and kicked her several times. Crosby subsequently left the house. Upon her return, she was informed by one of the officers that her partner was charging her with assault.

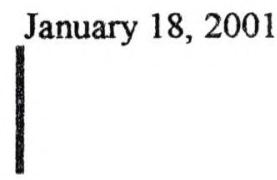




\section{APPENDIX F \\ MODERN HOMONEGATIVITY SCALE}

Gender: Male

Female

Age:

Please read each statement and choose the one most appropriate response to each statement: 1 (Strongly Disagree), 2 (Disagree), 3 (Neutral), 4 (Agree), or 5 (Strongly Agree)

1. Many lesbians use their sexual orientation so that they can obtain special privileges.

$\begin{array}{ccccc}1 & 2 & 3 & 4 & 5 \\ \text { Strongly Dissgree } & \text { Disagree } & \text { Neutral } & \text { Agree } & \text { Strongly Agree }\end{array}$

2. Lesbians seem to focus on the ways in which they differ from heterosexuals and ignore the ways in which they are the same.

$\begin{array}{ccccc}1 & 2 & 3 & 4 & 5 \\ \text { Strongly Disagree } & \text { Disagree } & \text { Neutral } & \text { Agree } & \text { Strongly Agree }\end{array}$

3. Lesbians do not have all the rights they need.

$\begin{array}{ccccc}1 & 2 & 3 & 4 & 5 \\ \text { Strongly Disagree } & \text { Disagree } & \text { Nentral } & \text { Agree } & \text { Strongly Agree }\end{array}$

4. The notion of universities providing students with undergraduate degrees in Gay and Lesbian Studies is ridiculous.

$\begin{array}{ccccc}1 & 2 & 3 & 4 & 5 \\ \text { Strongiy Disagree } & \text { Disagree } & \text { Neutral } & \text { Agree } & \text { Strongly Agree }\end{array}$

5. Celebrations such as "Gay Pride Day" are ridiculous because they assume that an individual's sexual orientation should constitute a source of pride.
1
2
Disagree
3
4
Agree
5
Strongly Agree

Strongly Disagree 
6. Lesbians still need to protest for equal rights.

$\begin{array}{ccccc}1 & 2 & 3 & 4 & 5 \\ \text { Strongly Disagree } & \text { Disagree } & \text { Neutral } & \text { Agree } & \text { Strongly Agree }\end{array}$

7. Lesbians should stop shoving their lifestyle down other people's throats.

$\begin{array}{ccccc}1 & 2 & 3 & 4 & 5 \\ \text { Strongly Disagree } & \text { Disagree } & \text { Neutral } & \text { Agree } & \text { Strongly Agree }\end{array}$

8. If lesbians want to be treated like everyone else then they need to stop making such a fuss about their sexuality/culture.

$\begin{array}{ccccc}1 & 2 & 3 & 4 & 5 \\ \text { Strongly Disagree } & \text { Disagr } & \text { Neutral } & \text { Agree } & \text { Strongly Agree }\end{array}$

9. Lesbians who are "out of the closet" should be admired for their courage.

$\begin{array}{ccccc}1 & 2 & 3 & 4 & 5 \\ \text { Strongly Disagree } & \text { Disagree } & \text { Neutral } & \text { Agree } & \text { Strongly Agree }\end{array}$

10. Lesbians should stop complaining about the way they are treated in society and simply get on with their lives.

$\begin{array}{ccccc}1 & 2 & 3 & 4 & 5 \\ \text { Strongly Disagree } & \text { Disagree } & \text { Neutral } & \text { Agree } & \text { Strongly Agree }\end{array}$

11. In today's tough economic times, Americans' tax dollars shouldn't be used to support lesbian organizations.

$\begin{array}{ccccc}1 & 2 & 3 & 4 & 5 \\ \text { Strongly Disagree } & \text { Disagree } & \text { Neưral } & \text { Agree } & \text { Strongly Agree }\end{array}$

12. Lesbians have become far too confrontational in their demand for equal rights.

$\begin{array}{ccccc}1 & 2 & 3 & 4 & 5 \\ \text { Strongly Disagree } & \text { Disagree } & \text { Neutral } & \text { Agree } & \text { Strongly Agree }\end{array}$




\section{APPENDIX G \\ PERCEPTIONS OF VIOLENCE SCALE}

Please read each statement and choose the one most appropriate response to each statement.

1. To what extent do you perceive the alleged victim as being a battered woman?

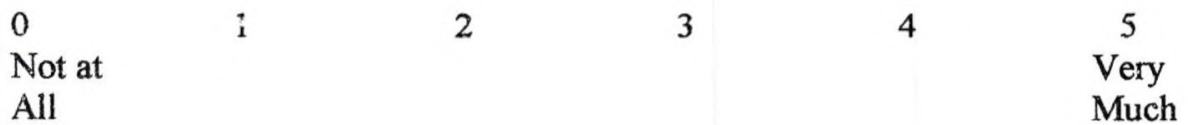

2. Please rate the assault that occurred on the night in question according to the following dimensions,

$\begin{array}{llllllll}\text { Not Serious } & 0 & 1 & 2 & 3 & 4 & 5 & \text { Serious }\end{array}$

$\begin{array}{llllllll}\text { Not Severe } & 0 & 1 & 2 & 3 & 4 & 5 & \text { Severe }\end{array}$

Improbable $\begin{array}{lllllll}0 & 1 & 2 & 3 & 4 & 5 & \text { Probable }\end{array}$

$\begin{array}{llllllll}\text { Not Realistic } & 0 & 1 & 2 & 3 & 4 & 5 & \text { Realistic }\end{array}$

3. On the evening in question, rate the degree to which you perceived the alleged victim as fighting back?

$\begin{array}{lllllc}0 & 1 & 2 & 3 & 4 & 5 \\ \text { Not at } & & & & & \begin{array}{c}\text { Very } \\ \text { Much }\end{array} \\ \text { All } & & & & & \end{array}$

4. If you had witnessed this incident from the window next door, how likely would it have been that you would have called the police?

$\begin{array}{llllll}0 & 1 & 2 & 3 & 4 & 5\end{array}$

Not at $\quad$ Very

All Likely

5. To what degree do you perceive the alleged victim as being trapped due to psychological factors?

$\begin{array}{lllllc}0 & 1 & 2 & 3 & 4 & 5 \\ \begin{array}{l}\text { Not at } \\ \text { All }\end{array} & & & & & \begin{array}{c}\text { Very } \\ \text { Much }\end{array}\end{array}$


6. To what degree do you perceive the alleged victim as being trapped due to the accused's domination and control?

$\begin{array}{llllcc}0 & 1 & 2 & 3 & 4 & 5 \\ \begin{array}{l}\text { Not at } \\ \text { All }\end{array} & & & & & \begin{array}{c}\text { Very } \\ \text { Much }\end{array}\end{array}$

7. To what degree do you perceive the alleged victim as being trapped due to financial constraints?

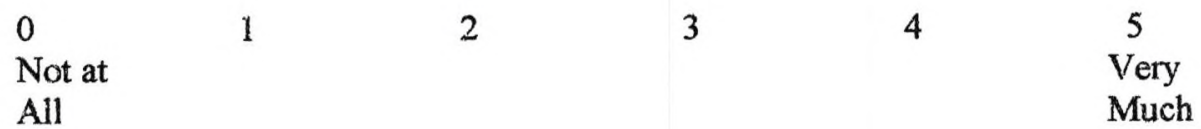

8. To what degree do you perceive the alleged victim as psychologically stable?

$\begin{array}{lllllc}0 & 1 & 2 & 3 & 4 & 5 \\ \text { Not at } & & & & & \text { Very } \\ \text { All } & & & & & \text { Much }\end{array}$

9. How honest do you find the alleged victim to be?

$\begin{array}{llllcc}0 & 1 & 2 & 3 & 4 & 5 \\ \begin{array}{l}\text { Not at all } \\ \text { Honest }\end{array} & & & & & \text { Very } \\ \text { Honest }\end{array}$

10. How much does the blame for the incident that evening rest solely on the accused?
0
1
2
3
4
5
Not at
Completely

All

11. How much does the blame for the incident that evening rest solely on the alleged victim?
0
1
2
3
4
5
Not at
Completely

All 
12. As far as crimes go, how violent was the incident?

$\begin{array}{llllcc}0 & 1 & 2 & 3 & 4 & 5 \\ \begin{array}{l}\text { Not at } \\ \text { All }\end{array} & & & & & \begin{array}{c}\text { Very } \\ \text { Much }\end{array}\end{array}$

13. How honest did you find the accused to be?

$\begin{array}{llllcc}0 & 1 & 2 & 3 & 4 & 5 \\ \begin{array}{l}\text { Not at All } \\ \text { Honest }\end{array} & & & & & \text { Very } \\ \text { Honest }\end{array}$

14. On the evening in question, rate the degree to which you perceived the accused to be mutually combative?

$\begin{array}{llllcc}0 & 1 & 2 & 3 & 4 & 5 \\ \text { Not at } & & & & & \text { Very } \\ \text { All } & & & & & \text { Much }\end{array}$

15. On the evening in question, rate the degree to which you perceived the accused to be mutually combative?
$0 \quad 1$
2
3
4
5
Not at
Very
All
Much

16. How much responsibility for the incident that evening rest solely on the alleged victim?
0
2
3
4
5
Not at
Completely

All

17. How much responsibility for the incident that evening rest solely on the accused?
1
2
3
4
5
Not at
Completely
All 
18. What is the likelihood that you would be friends with the accused?

$\begin{array}{llllcc}0 & 1 & 2 & 3 & 4 & 5 \\ \text { Not at } & & & & & \text { Very } \\ \text { All Likely } & & & & & \text { Likely }\end{array}$

19. What is the likelihood that you would be friends with the alleged victim?

$\begin{array}{llllcc}0 & 1 & 2 & 3 & 4 & 5 \\ \text { Not at } & & & & & \text { Very } \\ \text { All Likely } & & & & & \text { Likely }\end{array}$

20. How attractive is the alleged victim?

$\begin{array}{lllllc}0 & 1 & 2 & 3 & 4 & 5 \\ \begin{array}{l}\text { Not at } \\ \text { All }\end{array} & & & & & \begin{array}{c}\text { Very } \\ \text { Much }\end{array}\end{array}$

21. How attractive is the accused?

$\begin{array}{llllcc}0 & 1 & 2 & 3 & 4 & 5 \\ \text { Not at } & & & & & \begin{array}{c}\text { Very } \\ \text { Much }\end{array} \\ \text { All } & & & & & \end{array}$

22. Please answer the following demographic information

Gender: $\quad$ Male $\quad$ Female

Age:

Race/Ethnicity:

Asian-American

African-American

Caucasian

Hispanic

Native-American

Other

Sexual Orientation:

Heterosexual

Gay/Lesbian

Bisexual

Other 


\section{APPENDIX H \\ INFORMED CONSENT FORM PERCEPTIONS OF RELATIONAHIPS}

My name is Betsi Little, and I am a graduate student in the Department of Psychology at the University of North Dakota, and I am working on a research project to examine people's perceptions of relationships. This study will take approximately 45 minutes to an hour to complete.

You are invited to participate in a study in which you will be asked to view two pictures and then read a transcript involving a simulated police interview (based on actual elements reported in the literature pertaining to domestic violence) of an alleged victim of domestic violence. As well, you will be asked to respond to several questions that are designed to assess your opinions concerning a number of social and personal issues.

The benefits from this research will be a better understanding of how people perceive relationships. Specific benefits to you for your participation will be a better understanding of what psychological research is about, and the opportunity to earn extra credit in your current psychology class. Some people may find the issue of domestic assault to be offensive and upsetting therefore, you are under no obligation to continue with the study. Contact numbers for agencies will be provided at the end of the study for follow-up care if desired. Service listed are free of charge. Any charges for services that may arise, are the responsibility of the participant.

Some participants may feel a little apprehensive because this is an evaluative situation, or may feel anxious responding to questions pertaining to personally sensitive issues. You do not have to respond to any questions that you do not want to, and all data will remain confidential and anonymous with respect to your personal identity. To insure privacy concerns, participants will be given numerical identification numbers for processing the data and your names will not be revealed in presentation or publication of the study.

Questionnaires will be stored separately from consent forms in a locked cabinet in CorwinLarimor 115 for a period of three years.

Participation is voluntary. Your decision whether or not to participate will not affect your future relations with UND. If you decide to participate, you are free to discontinue participation at any time without prejudice. If you have any questions about this research, you may ask Betsi Little at 777-8805. Alternatively, you may contact the Thesis Committee Chair for this study, Dr. Cheryl Terrance at 777-3921.

If you have any other questions or concerns, pleasc sall the Office of Research and Program Development at 777-4279.

I have read all of the above and willingly agree to participate in this study.

Participants Name:

Witness's Name:
Date:

Date: 


\section{APPENDIX I \\ DEBRIEFING INFORMATION}

I would like to thank you for participating in this study. Your participation will help us understand more about the factors implicated in domestic violence situations that influence people's decisions.

I would like to emphasize the extreme seriousness of the crimes of domestic abuse. Victims of domestic abuse often suffer severe psychological and physical repercussions. Unfortunately many individuals hold various misconceptions or stereotypes with regard to battered men and women. Of the utmost importance is for people to become aware and to understand that victims of domestic violence are not responsible for the abuse that they may be subjected to, and that they are victims of traumatic and brutal abuse. Often, many barriers make it difficult or impossible for these women and men to escape from the violence of their partners. Financial restraints, fear for the safety and well-being of their children, psychological trauma, inadequacy of social alternatives, and fear of reprisal should (s)he indeed leave are all factors that influence the lives of these women and men. Under no circumstances should a woman or man be held responsible for his or her partner's abusive actions.

The purpose of the study in which you have participated was to investigate the influence of physical appearance on the perception of the victim. Specifically, I am looking at how much blame is attributed to the victim based on her physical apparance. Please note that the transcript presented to you is a totally simulated scenario, although it did include elements typically reported in domestic assault situations.

I appreciate your taking the time to answer the questions and want to stress that all of your answers are valuable. I understand that the scenarios may be upsetting and anxiety provoking for some people and I stress that you contact myself or one of the agencies listed on the back of this sheet if you have any concerns regarding this study or the issues referred to in this study. The list of contacts includes agencies within both the university and the community that are available for men and women. Services listed are free of charge. Any charges for services that may arise, are the responsibility of the participant.

Due to the nature of this research, I ask that you do not discuss this study with potential participants until testing is complete (approximately December of 2003). If you wish to discuss any additional aspects of the research, I am available for appointments.

If you have any questions regarding this experiment, you may contact Betsi Little in Corwin-Larimore 115 or by phoning 777-8805. 


\section{Contact Information}

Police Phone Numbers

Emergency 911

Grand Forks $787-8000$

Crisis Intervention

Crisis Intervention Help-Line

$1-800-472-2911$

Northeast Human Services Crisis Line

$775-0525$

Abuse and Rape Crisis Line

$746-8900$

Altru Health System

$780-5900$

Support Services

Community Violence Intervention Center $\quad 746-8900$

Grand Forks County Family Services

$787-8540$

Catholic Family Services

$775-4196$

Lutheran Social Services

$772-4418$

Counseling Services

UND Counseling Center

$777-2127$ 


\section{REFERENCES}

Aube, J., Norcliffe, H. and Koestner, R. (1995). Physical characteristics and the multifactorial approach to the study of gender characteristics. Social Behavior and Personality, 23(1), 69-82.

Balsam, K. (2001). Nowhere to Hide: Lesbian Battering, Homophobia, and Minority Stress. Women and Therapy, 23(3) 25-37.

Bologna, M., Waterman, C. and Dawson, L. (1987). Violence in gay male and lesbian relationships: Implications for practitioners and policy makers. Paper presented at the Third National Conference for Family Violence Researchers, Durham, NH.

Brand, P. A., \& Kidd, A. H. (1986). Frequency of physical aggression in heterosexual and female homosexual dyads. Psychological Reports, 59, 1307-1313

Burke, L. and Follingstad, D. (1999). Violence in Lesbian and Gay Relationships: Theory, Prevalence, and Correlational Factors. Clinical Psychology Review, $19(5)$ 487-512.

Cardell, M., Finn, St. and Marecek, J. (1981). Sex-role identity, sex-role behavior and satisfaction in heterosexual, lesbian and gay male couples Psychology of Women Quarterly, 5(3), 488-494. 
Cejka, M. and Eagly, A. (1999). Gender stereotypic images of occupations correspond to the sex segregation of employment. Personality and Social Psychology Bulletin, 25(4), 413-423.

Cogan, J. (1999). Lesbians Walk the Tightrope of Beauty: Thin is In but Femme is Out. Journal of Lesbian Studies, 3(4) 77-89.

Corley, T. and Pollack, R. (1996). Do Changes in the Stereotypic Depiction of a Lesbian Couple Affect Heterosexuals' Attitudes Toward Lesbianism? Journal of Homosexuality, 32(2), 1-17.

Deaux, K. and Lewis, L. (1983). Structure of Gender Stereotypes: Interrelationships Among Components and Gender Label. Journal of Personality and Social Psychology, 46(5), 991-1004.

Dodge, M. and Greene, E. (1991). Juror and expert conceptions of battered women. Violence and Victims. 6(4), 271-282.

Eagly, A. and Mladinic, A. (1989). Gender Stereotypes and Attitudes Toward Women and Men. Personality and Social Psychology Bulletin, 15(4), 543-558.

Esses, V., Haddock, G., and Zanna, M. (1993). Assessing the Structure of Prejudicial Attitudes: The Case of Attitudes Towards Homosexuals. Journal of Personality and Social Psychology, 65(5), 1105-1118.

Ewing, C. and Aubrey, M. (1987). Battered women and public opinion: Some realities about the myths. Journal of Family Violence. 2(3), 257-264. 
Frodi, A., Macaulay, J and Thome, P. (1977). Are women always less aggressive than men? A review of the experimental literature. Psychological Bulletin. 84(4), $634-660$.

Hamilton, D.L. (1981). Stereotyping and intergroup behavior: Some thoughts on the cognitive approach. Cognitive processes in stereotyping and intergroup behavior, 333-354.

Harris, R. and Cooke, C. (1994). Attributions About Spouse Abuse: It Matters Who the Batterers and Victims Are. Sex Roles, 4(7/8), 553-565.

Hart, B. (1986). Lesbian Battering: An examination. In K. Lobel (Ed.), Naming the violence (pp. 173-189). Seattle: Seal Press.

Hegstrom, J. and McCarl-Nielsen, J. (2002). Gender and metaphor: Descriptions of familiar persons. Discourse-Processes. 33(3), 219-234.

Hilton, J. and von Hippel, W. (1990). The Role of Consistency in the Judgement of Stereotype-Relevant Behaviors. Personality and Social Psychology Bulletin, $16(3), 430-448$.

Hilton, J. and von Hippel, W. (1996). Stereotypes. Annual Review if Psychology, 47, 237-71.

Jackson, L. and Cash, T. (1985). Components of gender stereotypes: Their implications for inferences on stereotypic and nonstereotypic dimensions. Personality and Social Psychology Bulletin. 11(3), 326-344.

Kite, M. and Deaux, K. (1987). Gender Belief Systems: Homosexuality and the Implicit Inversion Theory. Psychology of Women Quarterly, 11, 83-96. 
Kurdek, L. (1988). Perceived social support in gays and lesbians in cohabitating relationships. Journal of Personality and Social Psychology, 54(3), 504-509.

Letellier, P. (1994). Gay and Bisexual Male Domestic Violence Victimization: Challenges to Feminist Theory and Responses to Violence. Violence and Victims, $9(2), 95-107$.

Lie, G., \& Gentlewarrier, S. (1991). Intimate violence in lesbian relationships: discussion of survey findings and practice implications. Journal of Social Service Research, 15, 41-59.

Lie, G., Schlit, R., Bush, J., Montagne, M., \& Reyes, L. (1991). Lesbians in currently aggressive relationships: How frequently do they report aggressive past relationships? Violence and Victims, 6, 121-135.

Lockhart, L., White, B., Causby, V. and Isaac, A. (1994). Letting Out the Secret: Violence in Lesbian Relationships. Journal of Interpersonal Violence, 9(4), 469492.

Loulon, J. (1987). Lestian Passion Loving ourselves and each other. San Fransico: Spinsters, Aunt Lute.

Maccoby, E. (1990). The role of gender identity and gender constancy in sexdifferentiated development. New Directions for Child Development, 47, 5-20.

Madon, S. (1997). What Do People Believe About Gay Males? A Study of Stereotype Content and Strength. Sex Roles, 37(9/10), 663-685.

MacDonald, A. P., \& Games, R. G. (1974). Some characterisites of those who hold negative attitudes towards homosexuals. Journal of Homosexuality, 1, 9-28. 
McLaughlin, E. and Rozee, P. (2001). Knowledge About Heterosexual versus Lesbian Battering Among Lesbian. Intimate Betrayal: Domestic Violence in Lesbian Relationships. Haworth Press, Inc.

Noller, P. (1993). Gender and emotional communication in marriage: Different cultures or differentiai social power: Journal of Language and Social Psychology. 12(12), 132-152.

Peplau, L. (1983). Research on homosexual couples: An overview. Journal of Homosexuality, 8(2), 3-8.

Pitt, E. (2000). Domestic Violence in Gay and Lesbian Relationships. Journal of the Goy and Lesbian Medical Association, 4(4), 195-196.

Pitt, E. and Solan-Soto, D. (2001). Clinical Considerations in Working with Victims of Same-Sex Domestic Violence. Journal of the Gay and Lesbian Medical Association, 5(4), 163-169.

Ponse, B. (1978). Identities in the lesbian world. Dissertations Abstracts International. $38(1-\mathrm{A}) 504$.

Regan, P. and Sprecher, S. (1995) Gerder differences in the value of contributions to intimate relationships: Egalitarian relationships are not always perceived to be equitable. Sex Roles, 33(3-4), 221-238.

Renzetti, C. (1999). The Challenge io Ferninism Posed by Women's Use of Violence in Intimate Relationships. Women's Use of Violence in Intimate Relationships. 
Storms, M. (1979). Sex Role Identity and Its Relationships to Sex Role Attributes and Sex Role Stereotypes. Journal of Personality and Social Psychology, 37(10), 1779-1789.

Storms, M., Stivers, M., Lambers, S., and Hill, G. (1981). Sexual Scripts for Women. Sex Roles, 7(7), 699-707.

Tripp, C. (1975). The homosexual matrix. New York, NY, US: McGraw Hill.

Turell, S. (2000). A Descriptive Analysis of Same-Sex Relationship Violence for a Diverse Sample. Journal of Family Violence, 15(3), 281-293.

Waldner-Haugrud, L., Gratchm L., and Magruder, B. (199?). Sexual coercion in gay/lesbian relationships: Descriptive and 'no' differences. Violence and Victims, 12; 87-98.

Weinberg, G. (1972). Society and the healthy homosexual. New York: St. Martin's.

Wittenbrink, B., Gist, P. and Hilton, J. (1997). Structural properties of stereotypic knowledge and their influences on the construal of social situations. Journal of Personality and Social Psychology Bulletin, 72(3), 526-543.

Wood, D. (1987). A Statistical Analysis of Dominance, Possessiveness and Violence in Same-Sex and Opposite-Sex Dating Relationships, Unpublished master's thesis, University of Texas, Arlington,

Zipkin, D. (1999). The Myth of the Short-Haired Lesbian. Journal of Lesbian Studies, 3(4) $91-101$. 

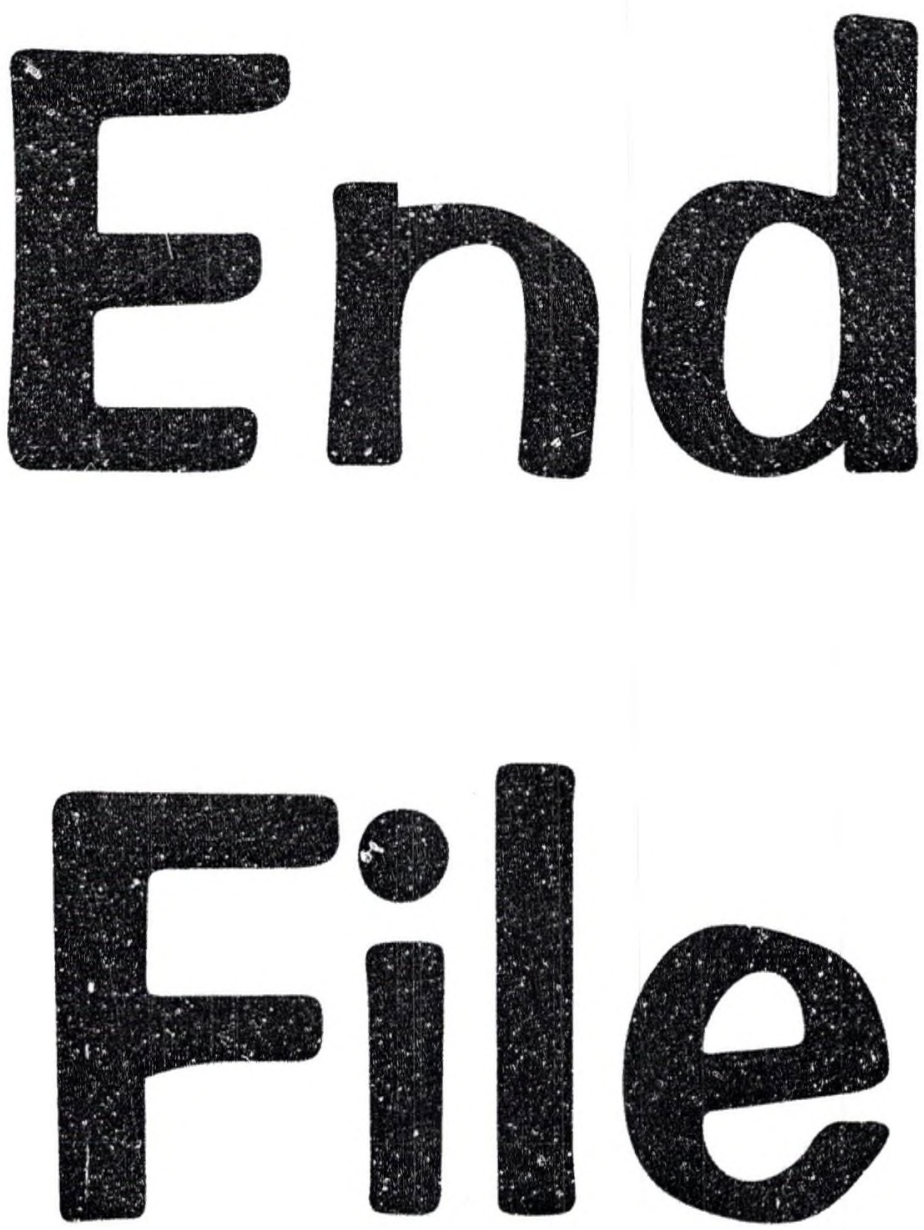